\title{
PERGESERAN OTORITAS ULAMA MAGETAN AKIBAT FRAGMENTASI MEDIA DAKWAH BARU YANG EKONOMIS
}

\author{
Abu Muslim \\ UIN Sunan Kalijaga Yogyakarta \\ abumuslimm04@gmail.com
}

\begin{abstract}
Abstrak
Melalui artikel ini penulis hendak menganalisis pergeseran otoritas ulama di Kabupaten Magetan sejak munculnya radio hingga youtube. Kajian ini diawali dengan sebelum ada radio terdapat tradisi mencari informasi agama kepada informan ustad, guru atau kiai yang harus ditempuh dengan jarak jauh dan membutuhkan waktu yang lama. Seiring dengan perkembangan tekhnologi, tradisi riblah tersebut mulai tergeser dengan youtube. Bagian dari internet ini memberi akses yang cukup mudah untuk mendapatkan informasi kepada khalayak dengan audio-visual hingga ke berbagai wilayah yang menembus batas geografis. Oleh sebab itu, artikel ini akan menganalisis mengapa pergeseran itu terjadi? Apa dampaknya pada otoritas ulama?. Hasil dari analisa penulis adalah adanya fragmentasi otoritas ulama itu berkaitan dengan media yang ekonomis.
\end{abstract}

Kata kunci: Informasi agama, media baru, otoritas ulama

\section{A. Pendahuluan}

Suatu peradaban dibentuk akibat bergulirnya pengetahuan hingga ditemukan penemuan-penemuan baru, baik sisi fungsional maupun bentuk metodis. Penemuan maupun informasi ini dibutuhkan untuk mengatasi persoalan kehidupan manusia yang semakin hari semakin komplek. Informasi ini tidak hanya bersifat persoalan agama namun juga persoalan pendidikan kesehatan dan lain sebagainya.

Begitu juga mengenai seseorang untuk mendapatkan informasi suatu keilmuan agama. Sebelum tekhnologi berkembang,

Spiritualis, vol. 5, no. 1, Maret 2019

ISSN: $2442-5907 \mid 30$ 
dulu para pencari ilmu, santri, murid harus menemui seorang informan yang ahli dalam bidangnya, seperti ustad, kiai, ulama. Bahkan untuk menemui informan tersebut, mereka rela menempuh perjalanan yang jauh bahkan membutuhkan waktu yang lama.

Para ulama fikih, tasawuf dan ulama-ulama ahli bidang lainya seperti al-Ghazali, untuk belajar logika dan filsafat, ia harus menempuh perjalanan Naisabur untuk berguru kepada ulama' SunniSyafi'i yaitu Imam al-Haramain al-Juwaini pada tahun $473 \mathrm{H}$ selama lima tahun. Selain itu, Di kota tersebut Imam al-Ghazali juga sempat belajar tasawuf kepada Abu Ali Al-Fadl bin Muhammad bin Ali alFarmadi. Setelah Imam al-Juwaini wafat, al-Ghazali kemudian melanjutkan riblah ilmiyahnya ke Baghdad. ${ }^{1}$

Contoh ulama lainya di Indonesia seperti Kiai Hasyim Asy'ari yang melakukan riblah ilmiahnya dari satu pondok ke pondok yang lain. Diantara pondok yang disinggahinya adalah pondok Shana dan pondok Siwalah di Sidoarjo. Hingga pergi ke Makkah untuk belajar berbagai disiplin ilmu seperti berguru kepada Syaikh Mahfudh al-Tirmisi dan Syaikh Ahmad Khatib. Setelah pulang dari riblah ilmiahnya, kemudian Kyai Hasyim Asy'ari mengajarkan ilmunnya kepada para santri di pondoknya.

Berbeda halnya dengan apa yang terjadi di Kabupaten Magetan. Seiring perkembangan zaman muncul tekhnologi eletronik seperti radio, televisi, internet, chanel youtube dan sebagainya menjadikan informasi bisa dihantarkan dengan cepat ke audiens. Misalnya media radio. Masyarakat Kabupaten Magetan hanya memutar chanel radio dengan jemari bisa menerima informasi. Da'i atau penceramah yang sering hadir atau muncul di radio seperti Kiai Zainuddin MZ. Kiai sejuta umat ini dalam pembawaanya menyampaikan materi dakwah dengan bahasa yang ringan, sehingga mudah dimengerti khalayak umum. Dia juga berusaha menyampaikan pesan yang menyentuh kepada audiens atau pendengar radio. Ciri khas yang selalu diingat oleh pendengar adalah

1 Abu Hamid Muhammad Al-Ghazali, Miyskat al-Anwar wa Mashafat al-Asrar. Beirut: Alam al-Kutub, 1986,18. 
kata 'betul' yang selalu diucapkannya saat bertanya kepada jama'ah. Sehingga menarik para pendengar masyarakat Magetan.

Perubahan yang cepat pada masyarakat juga akan membawa dampak pada pola pikir, sikap dan kepribadian masyarakat. Masyarakat yang mempunyai pola pikir tradisional akan berubah menuju kearah pola pikir modern yang lebih rasional, efisien, dan ekonomis serta pragmatis. Hal ini tentunya banyak mempengaruhi perkembangan penerimaan informasi akibat media baru yang ada. ${ }^{2}$

Selain itu, menurut Dale F. Eickelman munculnya kelas baru "aktivis Islam" di seluruh dunia muslim telah berlangsung seiring dengan penyebaran teknologi informasi baru, seperti kaset, CD audio, televisi satelit dan internet. Hal ini terjadi karena kaum muslim menampilkan diri dengan identitasnya di tengah masyarakat yang terus berubah dengan sifat agresifnya. Perubahan tersebut kemudian menciptakan struktur dan tatanan baru sehingga berdampak kepada perubahan pola-pola yang mapan dalam kehidupan masyarakat. ${ }^{3}$

Dari persoalan di atas memunculkan pertanyaan dalam benak penulis, bagaimana otoritas para ahli ilmu atau ulama, kiai, ustad Magetan yang tidak tampil pada media eletronik di era modern ini setelah banyak bermunculan para da'i yang memberi informasi di media eletronik itu? apa yang terjadi dengan ulama Kabupaten Magetan ketika muncul media baru serta ustad baru?.

\section{B. Media Baru Dan Penyebaran Informasi Melalui Dakwah}

Dulu sebelum eletronik jauh berkembang para santri untuk belajar suatu ilmu diharuskan berkelana menempuh jarak yang jauh dan waktu yang lama guna menemui seorang informan, yaitu guru, ustad, kiai atau ulama. Hal itu disebabkan karena akses untuk mendapatkan informasi hanya bisa dilakukan dengan menemui langsung dalam satu tempat. Belum ada handphone atau internet bahkan masih minim fasilitas transportasi.

2 Abdul Basit, Wacana Dakwah Kontemporer. Yogyakarta: Pustaka Pelajar, 2005, 31.

${ }^{3}$ Dale F. Eickelman, "New Media in the Arab Middle East and the Emergence of Open Societies', dalam Robert W. Hefner (ed.), Remaking Muslim Politics: Pluralism, Contestation, Democratization. Princeton: Princeton University Press, 2005, 37-59. 
Pada dasarsnya riḅlah ilmiah ini merupakan perjalanan untuk menuntut ilmu, mencari tempat belajar yang baik atau mencari guru yang otoritatif. Perjalanan seorang santri atau ilmuwan untuk menuju tempat kegiatan akademik bisa mencakup tujuan belajar-mengajar, diskusi, mencari kitab, dan seterusnya. ${ }^{4}$

Misalnya seorang muhadis dalam mencari satu ilmu atau hadis, mereka rela mendatangi informan dari berbagai sudut kota yang jauh untuk memperoleh pengetahuan mengenai suatu hadis. Riblah ini dianggap tindakan yang lebih mulia daripada hanya mempelajari buku-buku (kitâb). Bahkan meraka dalam rị̣lah-nya rela tidak tidur sepanjang malam, menempuh perjalanan yang jauh, mengarungi padang pasir dan memasuki berbagai negeri di tengah keterbatasan bekal dan sulitnya transportasi. ${ }^{5}$

Jābir ibn 'Abd Allāh (w. 78 H) misalnya ketika mendengar sebuah hadis yang konon berasal dari salah seorang sahabat 'Abd Allāh ibn Unais, lalu dia membeli unta untuk melakukan perjalanan. Dengan mengendarai unta tersebut ia melakukan perjalanan itu selama satu bulan hingga sampai di negeri Syria. Jābir pun menanyakan langsung hadis itu kepadanya.

Begitu juga masyarakat di kabupaten Magetan yang mayoritas masyarakat muslim untuk mengetahui suatu informasi tentang agama Islam, mereka harus pergi ke suatu pondok untuk bertanya, bahkan rela untuk tinggal di pondok. Cara seperti ini dulu lazim dan sering digunakan untuk mencari informasi ajaran agama Islam. Sehingga peran ulama di sini sangat menentukan sejauh mana memberikan informasi dan membentuk paradigma audiens.

Jumlah penduduk Kabupaten Magetan sampai dengan akhir Desember 2016 sekitar 640.931 jiwa. Sebagian besar penduduk Kabupaten Magetran menganut agama lslam yakni 625,127 penduduk, sedang penduduk lainya menganut agama Kristen 8.020.

${ }^{4}$ Hasan Asari, Menguak Sejarah Mencari Tbrah: Risalab Sejarah Sosial-Intelektual Muslim Klasik. Bandung: Citapustaka Media, 2006, 198.

${ }^{5}$ Munawar Ahmad Anees dan Alia N. Athar, Guide to Sira and Hadith Literature in Western Language. London: Manshell Publishing Limited, 1986, xix. 
penduduk Katolik 4.695, Hindu 256, dan Budha 2.833. Kabupaten yang berada di bagian barat provisi Jawa Timur ini setidaknya ada sekitar 54 pondok pesantren.

Ketika zaman mulai berkembang dan adanya kemajuan dalam bidang tekhnologi, lambat laun model belajar penduduk mulai bergeser. Kecanggihan tekhnologi yang memunculkan media baru yang ekonomis mampu memberi kemudahan para penggunanya. Seperti apa yang dikatakan Goran Larrson sebelum jauh adanya tekhnologi, tradisi oral masih menjadi media untuk mendapatkan suatu informasi. Setelah dunia jauh berkembang muncul media cetak yang kemudian dianggap menggeser peran guru atau ulama yang saat itu masih kental dengan tradisi oral. Setelah muncul media cetak kemudian muncul telepon, radio, televisi hingga intenet. Tekhnologi baru ini memberi kemudahan penggunanya yang mampu menembus batas geografis dan waktu. ${ }^{6}$

Pada pembahasan kali ini penulis hanya memilih tiga media yang masih melekat dan popular di masyarakat kabupaten Magetan. Sebab, sejauh pembacaan penulis, buku-buku, koran, maupun majalah lebih identik pada kaum sarjana ke atas atau tingkat yang mempunyai keilmuan yang lebih menonjol, dan hal ini rata-rata didominasi oleh mereka yang mempunyai pendidikan tinggi, baik secara formal maupun non-formal seperti madin atau pondok pesatren.

Tahap pertama yang dapat dianalisa adalah keberadaan radio. Radio ditemukan setelah adanya beberapa penemuan tekhnologi seperti telepon, fotografi dan rekaman suara. Tekhnologi yang menghantarkan informasi melalui suara ini memang murah, dan bisa didengarkan dimana-mana. Radio menstimulus suara dan menvisualisasikan suara penyiar atau informan faktual yang masuk pada telinga pendengarnya. ${ }^{7}$

6 Goran Larsson, Muslim And The New Media Historical And Contemporary Debates. Farnham: Ashgate, 2001.

7 Masduki, Jurnalistik Radio: Menata Profesianalisme Reported An Penyiar. Yogyakarta: LKIS, 2001, 3. 
Sementara dari penyelenggaraan penyiaran radio, dari aspek program siaran, kelebihannya adalah sifat-sifatnya: Pertama, personal, artinya pendengar dapat merasakan suasana akrab, sehingga informasi mudah tersalurkan. Kedua, komprehensif, yaitu segala informasi selalu cakap, tepat dan jelas. Ketiga, siaran radio bisa menjadi solusi bagi orang yang memiliki kelemahan buta huruf. Pendengar tidak dituntut harus pandai baca-tulis. Dengan demikian, radio secara simultan bisa mendramatisir situasi pendengar dalam jarak jauh, sehingga pendengar dengan sadar menerima pesan atau informasi dengan mudah. Sebagaimana diketahui bahwa radio adalah media eletronik yang murah, mudah (fortable) di bawa kemana-mana dan bahasa yang digunakan adalah bahasa telinga yang mudah dicerna dan dimengerti. ${ }^{8}$

Begitu juga kegiatan ceramah, da'i berdakwah menyampaiakan materi melalui radio. Pesawat radio dapat dijangkau oleh pendengarnya dalam jarak jauh dan luas sesuai batas dalam jangkuan frekuensi radio tersebut. Selain itu juga persoalan waktu, kapapun bisa dihantarakan seorang yang berceramah baik live maupun rekaman. Hal ini mempermudah bagi pendengar atau audiens dan penceramah atau da'i yang tidak memerlukan tatapan wajah secara langsung namun suara sudah hadir ditelinga audiens. Sehingga dengan demikian materi atau informasi cepat masuk dalam ruang pendengar.

Da'i atau penceramah melalui radio di Indonesia misalnya Kiai Zainuddin MZ. Kiai sejuta umat ini membawakan materi dakwahnya dengan bahasa ringan, sehingga mudah dimengerti masyarakat luas. Dia juga berusaha menyampaikan pesan yang menyentuh kepada audiens atau pendengar radio. Ciri khas yang selalu diingat oleh pendengar adalah kata 'betul' yang selalu diucapkannya saat bertanya kepada jama'ah.

Memang, pada masa-masa awal Radio muncul belum banyak jumlah para da'i. Sebab, selain kemampuan berbicara di radio, figure ketokohan juga mempengaruhi program radio tersebut yang

${ }^{8}$ Ibid. 
berimplikasi pada jumlah peminat pendengar radio tersebut. Masyarakat Magetan ketika radio mulai berkembang banyak masyarakat yang mampu untuk membeli alat komunikasi tersebut. Kalangan masyarakat yang sering mendengarkan radio di Kabupaten Magetan adalah para orang tua. Sebab menurut mereka sampai saat ini tradisi ini terbawa dari masih muda. Radio dinilai menjadi barang berharga untuk mendapatkan informasi baik soal agama dan juga informasi lain seperti berita dan program-program budaya seperti wayang kulit. Implikasinya adalah tidak sedikit dari mereka mulai mengerjakan apa yang dikatakan ustad atau da'i radio tersebut.

Respon yang tidak jauh berbeda saat kemunculan televisi. Kehadiran media ini direspon dengan baik oleh kaum agamis. Keunggulan media televisi dibandingkan dengan radio adalah audiovisual. Televisi memiliki kemampuan untuk mengakses publik hingga ke ruang pribadi. Pesan yang disampaikan di dalam televisi memiliki perpaduan gambar dan suara, sehingga lebih menarik sekaligus memberi pengaruh yang kuat terhadap perubahan dalam diri pemirsanya.

Televisi diyakini mampu menembus tembok kamar-kamar tidur keluarga yang tidak mungkin ditembus oleh individu. Besarnya magnet media terhadap khalayak menjadikan televisi mampu menyedot perhatian pemirsa 5 hingga 6 jam untuk menonton acara televisi. 'Televisi nasional maupun lokal, hampir tiap pagi dan sore di seluruh penjuru nusantara disuguhi dengan berbagai macam siraman rohani baik berupa ceramah, dialog interaktif maupun dakwah. Adanya berbagai macam cara dakwah di media televisi ini menunjukkan bahwa era informasi dan teknologi dimanfaatkan dengan baik untuk kegiatan dakwah.

Kemudahan yang ditawarkan televisi ini juga dirasakan oleh sebagian masyarakat Magetan. Menurut mereka hanya dengan duduk di rumah dan memencet remote sudah mendapatkan informasi yang mereka inginkan tentang ceramah para ustad-ustadzah di televisi atau

${ }_{9}$ WahyuWibowo (ed), Kedaulatan Frekuensi. Regulasi Penyiaran, Peran KPI dan Konvergensi Media. Jakarta: PT. Kompas Media Nusantara, 2013. 
acara yang lain. Meski acara ceramah di televisi tidak sering muncul setiap jam namun menurut masyarakat Magetan acara tersebut menarik untuk dilihat. Meski demikian, media televisi terkadang juga belum mampu untuk menjawab persoalan yang terjadi di masyarakat. Hal ini disebabkan oleh karena yang dihadirkan oleh televisi sesuai dengan apa yang telah diprogram pada acara tersebut bukan disesuaikan pada persoalan setiap masyarakat yang menonton.

Pemanfaatan televisi sebagai media dakwah juga tidak terlepas dari penyebarkan informasi mengenai ajaran-ajaran Islam. Dakwah melalui visualisasi ini lebih menarik dibanding dengan menggunakan media radio. Sebab sesuatu yang dilihat dan didengar itu akan lebih mudah diserap dan dicerna oleh panca indera manusia daripada hanya di dengar seperti melalui media radio maupun media cetak dan buku-buku. Bahkan jika para penceramah di televisi mampu hadir dengan guyonan atau banyolan maka dia akan menjadi idola pemirsanya.

Ustad yang sering tampil di televisi misalnya Ustad Maulana. Ustad yang sering menyapa jamaah dengan kalimat "jamaah oh jamaah, alhmdulillah" ini menarik banyak peminat. Dengan gaya khasnya tersebut dengan disusupi nilai-nilai ajaran Islam sering kali menghibur dan menarik para pemirsanya.

Begitu juga sebagian masyarakat Magetan kalangan dewasa hingga orang tua sering melihat ceramah-ceramah di televisi misalnya seperti ustad Maulana. Dengan khasnya tersebut sehingga program televisi ini sering ditonton oleh mereka. Selain mendapatkan informasi keagamaan namun juga terhibur dengan variasi guyonan atau bercandaaan yang dihadirkan oleh Ustad Maulana di acara "Islam itu Indah".

Begitu juga munculnya tekhnologi internet dan dalam perkembangannya hadir suatu chanel yang menghadirkan audio visual atau video yakni youtube. Saat ini youtube populer karena memiliki banyak manfaat dan kemudahan bagi pengunjungnya. Youtube memberikan kemudahan penggunan internet untuk mengunggah dan men-download video. Selain itu media youtube 
memiliki kelebihan dapat digunakan secara berulang-ulang dan dapat disimpan sebagai dokumentasi. ${ }^{10}$

Keunggulan ini cenderung digunakan sebagai salah satu sarana untuk berdakwah. Dengan youtube banyak hal yang dapat dibagikan seseorang untuk melakukan banyak hal serta berbagai cara dan konten bagaimana mereka menyebarluaskan suatu informasi. Kemudahan yang ditawarkan youtube ini tak pelak banyak bermunculan penceramah-penceramah yang meng-upload video ceramahnya. Misalnya Ustad Abdul Somad, Felix Xiau dan lain sebagainya. Kemunculanya para ustad dari youtube tersebut menyebabkan mereka menjadia tenar ke penjuru Indonesia, bahkan dunia.

Hadirnya youtube baru-baru ini juga menjadi pecandu bagi kaum muda Magetan. Kemudahan yang selalu digenggaman adalah alasan mereka mengapa youtube ini disukai. Selain itu, juga bisa diputar berulang-ulang bahkan kaum muda tersebut sering mendownload video ceramah tersebut agar dapat dilihat berulang-ulang. Masyarakat juga bisa memilih sesuka mereka sejauh youtube menyediakan berbagai konten isi ceramah dari berbagai da'i yang mengunggahnya.

Transisi dari tradisi oral antara pertemuan secara langsung face to face antara informan dengan audiens bergeser kepada penggunaan media komunikasi masa saat ini memang imbas dari globalisasi. Era ini identik dengan intensitas komunikasi yang semakin tinggi serta persoalan batas geografis yang dulu harus ditempuh dengan perjalanan jauh namun kini tidak masalah. Sebab, globalisai ini menembus batas penghalang ruang dan waktu. Era yang ditandai dengan kemajuan tekhnologi ini mempermudah seseorang memberikan informasi kepada audiens langsung hadir melalui audio-visual yang bisa didengar atau ditonton di rumah atau tempat lainya. Tidak hanya terbatas satu audiens, namun bisa banyak

10 Deni Darmawan \& Deden Hendra Permana, Desain dan Pemprograman Website. Bandung, Remaja Rosdakarya, 2013, 2. 
audiens di mana saja dengan syarat masih tersambung dengan jaringan satelit, baik radio-televisi maupun internet.

Di era informasi seperti sekarang ini melakukan dakwah tidak tidak cukup hanya menggunakan pengajian di mushalla atau masjid, karena model seperti ini hanya dapat diikuti oleh mereka yang hadir di tempat tersebut. Namun dengan penggunaan mediamedia komunikasi modern seseorang bisa menikmati konten ceramah dengan efektif dan efisien karena media modern lebih ekonomis. Keberadaan media ini bukan hanya untuk kepentingan menyampaikan ajaran-ajaran Islam atau dakwah Islam saja. Lebih dari itu media memiliki kekuatan untuk mempengaruhi aspek kognitif, afektif dan behavior audiens sehingga apa yang dikatakan oleh para da'i dapat tercapai oleh audiens.

Tabel transisi dan transformasi informasi melalui media baru.

\begin{tabular}{|c|l|l|l|l|l|}
\hline No & Media & Time & Pola kerja & $\begin{array}{l}\text { Ruang } \\
\text { /space }\end{array}$ & $\begin{array}{c}\text { Bentuk } \\
\text { perubahan }\end{array}$ \\
\hline 1. & $\begin{array}{c}\text { Guru, } \\
\text { ustad, } \\
\text { kiai, } \\
\text { ulama }\end{array}$ & $\begin{array}{l}\text { Tertentu } \\
\text { atau } \\
\text { terbatas }\end{array}$ & $\begin{array}{l}\text { Menyampaikan } \\
\text { secara face to } \\
\text { face/ } \\
\text { berhadapan } \\
\text { secara langsung }\end{array}$ & $\begin{array}{l}\text { Satu } \\
\text { ruangan } \\
\text { dengan } \\
\text { informan }\end{array}$ & $\begin{array}{l}\text { Hanya sebatas } \\
\text { mereka yang } \\
\text { menemui guru/ } \\
\text { informan }\end{array}$ \\
\hline 2. & $\begin{array}{l}\text { Radio } \\
\text { (Audio) }\end{array}$ & $\begin{array}{l}\text { Tertentu } \\
\text { atau } \\
\text { terbatas } \\
\text { sesuai } \\
\text { jadwal } \\
\text { siaran }\end{array}$ & $\begin{array}{l}\text { Menyampaikan } \\
\text { kepada tiap } \\
\text { orang sejauh } \\
\text { frekuensi radio } \\
\text { beredar hanya } \\
\text { dengan melalui } \\
\text { suara }\end{array}$ & $\begin{array}{l}\text { Berbagai } \\
\text { ruangan } \\
\text { sejauh } \\
\text { frekuensi } \\
\text { radio } \\
\text { beredar }\end{array}$ & $\begin{array}{l}\text { Sejauh informasi } \\
\text { pada radio tersebut } \\
\text { didengar dan lebih } \\
\text { umum (anak-anak, } \\
\text { orang dewasa dll) }\end{array}$ \\
\hline 3. & $\begin{array}{l}\text { Televisi } \\
\text { (Audio } \\
\text { dan } \\
\text { Visual) }\end{array}$ & $\begin{array}{l}\text { Tertentu } \\
\text { atau } \\
\text { terbatas } \\
\text { sesuai } \\
\text { jadwal } \\
\text { siaran }\end{array}$ & $\begin{array}{l}\text { Menyampaikan } \\
\text { kepada tiap } \\
\text { orang sejauh } \\
\text { frekuensi } \\
\text { televisi beredar } \\
\text { dengan melalui } \\
\text { suara dan } \\
\text { gambar }\end{array}$ & $\begin{array}{l}\text { Berbagai } \\
\text { ruangan } \\
\text { sejauh } \\
\text { frekuensi } \\
\text { televisi } \\
\text { beredar }\end{array}$ & $\begin{array}{l}\text { Sejauh informasi } \\
\text { pada televisi } \\
\text { tersebut dilihat dan } \\
\text { lebih umum (anak- } \\
\text { anak, orang dewasa } \\
\text { dll) }\end{array}$ \\
\hline 4. & $\begin{array}{l}\text { Chanel } \\
\text { youtube }\end{array}$ & $\begin{array}{l}\text { Kapan saja } \\
\text { sejauh }\end{array}$ & $\begin{array}{l}\text { Menyampaikan } \\
\text { kepada tiap }\end{array}$ & $\begin{array}{l}\text { Berbagai } \\
\text { ruangan }\end{array}$ & $\begin{array}{l}\text { Sejauh informasi } \\
\text { pada youtube }\end{array}$ \\
\hline
\end{tabular}


Spiritualis, vol. 5, no. 1, Maret 2019|40

\begin{tabular}{|c|c|c|c|c|}
\hline $\begin{array}{l}\text { (Audio } \\
\text { dan } \\
\text { Visual) }\end{array}$ & $\begin{array}{l}\text { tersambug } \\
\text { dengan } \\
\text { layanan } \\
\text { internet }\end{array}$ & $\begin{array}{l}\text { orang sejauh } \\
\text { frekuensi } \\
\text { internet } \\
\text { beredar bahkan } \\
\text { melebihi } \\
\text { televisi dengan } \\
\text { melalui suara } \\
\text { dan gambar }\end{array}$ & $\begin{array}{l}\text { sejauh } \\
\text { frekuensi } \\
\text { internet } \\
\text { beredar }\end{array}$ & $\begin{array}{l}\text { tersebut dapat } \\
\text { diakses dan } \\
\text { pengguna lebih } \\
\text { umum (anak-anak, } \\
\text { orang dewasa dll) }\end{array}$ \\
\hline
\end{tabular}

\section{Fragmentasi Media Baru, Audiens Baru dan Otoritas Ulama}

Suatu proses transformasi dari suatu arah ke arah yang lebih maju dalam berbagai aspek kehidupan masyarakat memang sedang dirasakan di era milineal saat ini. Secara sederhana dapat dikatakan bahwa proses perubahan dari cara tradisional ke cara baru yang lebih maju dimaksudkan untuk memudahkan masyarakat dalam mendapatkan informasi. Hal ini senada dengan pendapat Wilbert E. Moore yang mengemukakan bahwa modernisasi merupakan suatu proses transformasi kehidupan yang tradisional atau pra modern dalam arti teknologi serta organisasi sosial ke arah pola ekonomis dan politis yang menjadi ciri-ciri negara barat yang stabil. ${ }^{11}$

Perubahan sosial tersebut melahirkan perubahan-perubahan di dalam struktur dan fungsi suatu sistem kemasyarkatan. Perubahan itu dapat diartikan sebagai suatu variasi cara hidup yang telah diterima oleh masyarakat. Perubahan-perubahan tersebut baik dari segi kondisi geografis, kebudayaan, agama, material, komposisi penduduk, idiologi, maupun difusi atau penemuan-penemuan baru yang ada di dalam masyarakat tersebut. ${ }^{12}$

Penggunaan media komunikasi, dapat dijadikan indikasi kalau era pertumbuhan dan perkembangan media berdasarkan gejalanya telah mengubah pola aktifitas anggota masyarakat. Pola pergeseran tersebut dapat dilihat dari penggunaan media komunikasi

\footnotetext{
11 Wilbert E. Moore, "Social Verandering" dalam Social Change, terj. A. Basoski \& Prisma Boeken, Utrech" Antwepen, 1965, 129.

12 Lihat Sorjono Soekanto, Sosiologi Suatu Pengantar. Jakarta: Raja Grafindo Persada, $1994,384$.
} 
lama menuju ke media komunikasi baru. Dalam konteks politik, media komunikasi baru ini memiliki ciri politis karena dapat menyatukan para pengguna secara virtual selayaknya sebuah organisasi dalam kehidupan nyata sehingga membentuk ruang baru dan pengguna atau audiens baru. ${ }^{13}$

Vin Crosbie mengatakan ada tiga media komunikasi yang selama ini berlangsung. Pertama, media interpersonal atau antar individu yang disebut dengan "one to one". Media ini saling komunikasi atau tukar informasi satu orang dengan seseorang yang lain. Kedua, mass media, media ini digunakan sebagai sarana menyebarluaskan informasi dari satu orang ke banyak orang (one to many). Lalu yang ketiga, disebut new media. Perbedaan dari kedua media sebelumnya adalah media ini lebih jauh digunakan untuk mengkomunikasi ide maupun informasi dari banyak orang ke banyak orang lainnya (many to many). ${ }^{14}$

Sejalan dengan indikasi tersebut, penelitian ini bermaksud untuk meneliti lebih jauh menyangkut fenomena aktifitas masyarakat Magetan mengenai cara mendapatkan informasi ajaran agama kemudian yang membentuk audiens baru dalam kaitannya penggunaan media baru yang berdampak pada otoritas ulama.

\section{Audiens Baru}

Radio yang mevisualkan dengan suara memang pada awalnya menjadi media yang menarik bagi masyarakat Magetan. Sebab radio yang bisa menjangkau berbagai sudut tempat sejauh frekuensi memudahkan untuk memberikan informasi.

13 Sains-positivistik bagian dari letupan semangat rasionalitas, telah menjadi pedoman hidup baru dalam masyarakat modern. Di era milineal sains telah menjadi "agama" baru yang dijadikan sebagai standar utama untuk mengukur absah tidaknya kebenaran. Sebuah kebenaran baru bisa dianggap sebagai kebenaran manakala ia memenuhi kualifikasi yang digariskan oleh sains. Maka saintisme dan positivisme berarti bahwa metode ilmu pengetahuan alam modern yang membatasi dari hanya sampai menetapkan fakta-fakta (bukannya nilai-nilai) adalah satu-satunya cara untuk menentukan kebenaran.

14 Vin Crosbie, Rebuilding Media, http: // rebuildingmedia. corante. Com / archives /2006 /04 /27 / what_is_new_media. php. Diakses pada tanggal 30 Mei 2018. 
Kemudahan ini menjadikan radio memiliki audiens yang lebih banyak dari pada informan sehingga membentuk audiens baru yakni audiens radio atau pendengar radio.

Pergeseran audiens dari informan ke radio membentuk audiens baru maka bergeser pula otoritas ulama. Kendati demikian, pergeseran ini memang tidak terlalu luas. Sebab pada saat itu para da'i tidak mudah masuk ke ruang radio untuk melakukan aktifitas ceramah. Sehingga tidak banyak merubah cara berfikir masyarakat akibat mendapatkan informasi dari ceramah radio tersebut.

Sementara itu, terkait informasi ceramah melalui media televisi yang menghantar suara dan gambar ini berkembang setelah radio. Kesamaan dengan radio adalah televisi juga memliki kemudahan untuk menghantarkan informasi ke ruang publik sejauh frekunsi. Mengenai ceramah juga sering muncul di televisi baik pagi hari maupun petang. Seiring perkembangan televisi menuju dunia industri juga berdampak pada program-program yang dihadirkan ke ruang publik.

Tidak luput program-program ceramah sehingga banyak bermunculan ustad-ustadzah seleb yang sering menghiasi layar kaca. Kemudahan televisi bisa dijangkau masyarakat sehingga membentuk ruang baru dan audiens baru, yakni audiens televisi dan ruang televisi. Biasanya ruang keluraga di era sekarang lebih banyak diisi dengan televisi, sehingga audiens mulai bergeser dari radio menuju televisi yang membentuk audiens baru berimplikasi pada pergeseran otoritas ulama pula yang lebih besar dari media radio.

Sedang youtube juga mempunyai kesamaan dan perbedaan dengan televisi dalam kemudahannya untuk menyebarkan informasi. Perbedaanya adalah pemilik video youtube dengan mudah untuk mengunggah video ke youtube. Begitu juga video ceramah dapat diunggah di youtube sehingga memunculkan banyak video-video ceramah yang memberikan informasi ke ruang publik. Di sisi lain audiens memiliki keterjangkuan akses 
youtube juga, sehingga mempermudah untuk mengkonsumsi video-video tersebut.

Selain itu, jangkauan akses youtube melebihi televisi yang hanya melalui beberapa program siaran televisi, namun youtube dapat sering dilihat sewaktu-waktu dengan syarat masih terjangkau dengan akses internet. Hal ini berdampak pada audiens youtube lebih banyak dari pada televisi sehingga membentuk ruang baru dan audiens baru yang lebih besar daripada televisi. Pergeseran dari ruang baru dan audiens baru yang lebih besar dari televisi ini berimplikasi juga pada pergeseran otoritas ulama yang lebih besar.

Sebagaimana penelitian Irwansyah, bahwa jaringan komunikasi sosial melalui new media lebih potensial di negara Indonesia. Dikatakan demikian karena media massa memiliki jangkauan terbatas karena kebiasaan membaca rendah atau tingkat ekonomi yang rendah, sehingga berdampak pada kemampuan membayar langganan yang lebih sedikit. Namun, dalam masyarakat tradisional, jaringan sosial yang lebih kuat. Dengan meningkatnya pengguna internet, khususnya kenaikan pengguna ponsel, jangkauan media sosial memiliki peluang paling potensial.

\section{Pergeseran Otoritas Ulama}

Menurut Naisbitt dan Aburdene ketika tekhnologi maju menyerbu masyarakat berkembang yang pada umumnya sudah mempunyai nilai-nilai yang mapan kini mulai merasa terancam. Masyarakat berkembang ini mulai merasakan bahwa nilai-nilai yang mereka anut akan berubah, bahkan tergilas dan hilang dan digantikan nilai-nilai global. Pola perliaku gaya lama berubah menuju gaya baru. Kemudian Naisbitt dan Aburdene

15 Irwansyah, Teknologi Komunikasi Sebagai Eksistensi Kekerabatan: Studi Analisa Jaringan Sosial Kekerabatan Berbasis Teknologi Komunikasi Telepon Seluler. Jakarta: Universitas Indonesia, 2010. 
Spiritualis, vol. 5, no. 1, Maret 2019|44

menyebutnya "imperialisme kultural". ${ }^{16}$ Naisbitt dan Aburdene menambahkan mengutip George Anne Geyer bahwa imperialsme kultur masuk ke suatu negara melalui radio, televisi, turis, perawat tentara perdamaian yang melangkahkan kakinya ke negara kuno yang menderita. Menurut mereka efek dari imperialisme kultural dihadapkan dengan homogenisasi yang tumbuh, masyarakat akan melestarikan identitas diri mereka, baik itu soal agama, kultur, kebangsaan, bahasa atau ras. ${ }^{17}$

Sementara itu, otoritas keagamaan adalah sebuah kemampuan atau kekuatan untuk menentukan keyakinan dan praktik yang benar, dan mempengaruhi pandangan sehingga melakukan sesuai dengan kehendak tertentu. Dalam agama-agama monoteistik yang berdasar pada kitab suci, otoritas keagamaan lebih melibatkan kekuasaan untuk menyusun serta menentukan kanon "otoritatif" teks dan metode penafsiran yang sah. Singkatnya, otoritas terkait erat dengan gagasan legitimasi atau kekuasaan. Otoritas keagamaan bisa berasal dari perorangan, kelompok orang, atau lembaga.

Melihat gejala di atas, kemudahan akses media baru seperti radio televisi hingga youtube memang berbeda-beda. Radio yang hanya meliputi sejauh frekuensi radio, begitu juga televisi, namun youtube memiliki space yang lebih luas lagi. ${ }^{18}$ Apabila dilihat dari penggunaan radio dengan jangkuannya terbatas dan jumlah muslim di Kabupaten Magetan, maka kemungkinan perubahan pola pikir masyarakat tersebut hanya mencapai sebesar peminat radio tersebut. Pada posisi ini otoritas ulama tergeser sejauh peminat radio warga muslim di kabupaten Magetan.

16 Jhon Naisbitt dan Patricia Aburdene, Megatrends 2000. Jakarta: Binarupa Aksara, 2000, 125.

17 Ibid., 133-134.

18 Teknologi yang digambarkan sebagai "media baru" adalah media digital yang memiliki karakteristik yang dapat dimanipulasi, bersifat jaringan, padat, interaktif dan tidak memihak. Beberapa contoh dapat disebut: internet, website, komputer multimedia, permainan komputer, CD-ROMS, dan DVD. LevManovich, "New Media From Borges to HTML." dalam Noah Wardrip- Fruin dan Nick Montfort(eds.), The New Media Reader. Cambridge\& Massachusetts, 2003, 13-25. 
Sementara itu, akses kemudahan televisi dengan jangkuannya yang dikaitkan dengan kondisi peminat pemirsa ceramah televisi dan jumlah muslim di kabupaten Magetan merubah pola pikir masyarakat Magetan hanya mencapai sebesar pemirsa televisi tersebut. Pada posisi ini otoritas ulama tergeser sejauh pemirsa televisi warga muslim di Kabupaten Magetan yakni lebih besar daripada radio sesuai peminat pemirsa televisi yang lebih besar daripada radio.

Begitu juga dengan chanel youtube, akses kemudahan youtube dengan jangkuannya dikaitkan dengan kondisi peminat ceramah youtube di Kabupaten Magetan, kemungkinan merubah pola pikir masyarakat Magetan mencapai sebesar pemirsa youtube tersebut. Pada posisi ini otoritas ulama tergeser sejauh peminat youtube warga muslim di kabupaten Magetan. Pengaruh youtube jauh lebih besar dari pada radio dan televisi sesuai peminat youtube yang lebih besar dari pada radio dan televisi. sehingga menunjukan otoritas ulama ini lebih besar tergeser dengan adanya youtube.

\begin{tabular}{|c|l|l|l|l|}
\hline No & Media & $\begin{array}{l}\text { Pergeseran } \\
\text { Otoritas }\end{array}$ & $\begin{array}{l}\text { Ruang } \\
\text { Baru }\end{array}$ & $\begin{array}{l}\text { Bentuk } \\
\text { Perubahan } \\
\text { Behavior }\end{array}$ \\
\hline 1 & $\begin{array}{l}\text { Ustad, kiai, } \\
\text { ulama (face to } \\
\text { face/ tradisi } \\
\text { oral) }\end{array}$ & $\begin{array}{l}\text { Belum } \\
\text { tergeser }\end{array}$ & $\begin{array}{l}\text { Tidak ada } \\
\text { ruang baru }\end{array}$ & $\begin{array}{l}\text { Perilaku berubah } \\
\text { sesuai apa yang } \\
\text { dikatakan ustad, } \\
\text { kiai atau ulama } \\
\text { tersebut }\end{array}$ \\
\hline 2 & $\begin{array}{l}\text { Radio } \\
\text { (audio) }\end{array}$ & Bergeser & $\begin{array}{l}\text { Para } \\
\text { pendengar } \\
\text { radio }\end{array}$ & $\begin{array}{l}\text { Perilaku berubah } \\
\text { sesuai apa yang } \\
\text { dikatakan oleh } \\
\text { siaran radio tersebut }\end{array}$ \\
\hline 3 & $\begin{array}{l}\text { Televisi } \\
\text { (audio } \\
\text { visual) }\end{array}$ & Bergeser & $\begin{array}{l}\text { Para } \\
\text { pemirsa } \\
\text { televisi }\end{array}$ & $\begin{array}{l}\text { Perilaku berubah } \\
\text { sesuai apa yang } \\
\text { dikatakan ustad, } \\
\text { kiai/ulama yang }\end{array}$ \\
\hline
\end{tabular}




\begin{tabular}{|c|c|c|c|c|}
\hline & & & & $\begin{array}{l}\text { ceramah pada siaran } \\
\text { televisi tersebut }\end{array}$ \\
\hline 4 & $\begin{array}{l}\text { Youtube } \\
\text { (audio } \\
\text { visual) }\end{array}$ & Bergeser & $\begin{array}{l}\text { Para } \\
\text { pengguna } \\
\text { video } \\
\text { youtube }\end{array}$ & $\begin{array}{l}\text { Perilaku berubah } \\
\text { sesuai apa yang } \\
\text { dikatakan ustad, } \\
\text { kiai,/ulama yang } \\
\text { ceramah pada } \\
\text { chanel youtube } \\
\text { tersebut }\end{array}$ \\
\hline
\end{tabular}

Melihat bagaimana media baru yang membentuk audiens baru dalam warga muslim Kabupaten Magetan, setidaknya dapat dikatakan bahwa otoritas ulama yang bergeser pada tiap tiap peminat media baru, maka akibat dari fragmentasi media baru tersebut otoritas ulama Magetan dapat dikatakan bergeser.

\section{Kesimpulan}

Setelah melakukan penelitian penulis menyimpulkan, pertama kontestasi ceramah yang merupakan penyebaran informasi tentang ajaran agama melalui media radio, televisi dan youtube memang berbeda-berbeda. Pertama, Radio dengan mevisualkan suaranya memberi informsi sejauh frekuensi radio. Begitu juga televisi memberikan informasi sejauh jaringan freuensi televisi. Berbeda dengan youtube yang merupakan bagian dari internet maka memberikan informasi bisa menembus batas wilayah yang lebih luas. Kedua, dampak ceramah melalui media baru, baik melalui radio, televisi atau youtube tersebut, dapat menimbulkan pergeseran otoritas ulama lebih besar. 
Spiritualis, vol. 5, no. 1, Maret 2019|47

\section{DAFTAR PUSTAKA}

Asari, Hasan. Menguak Sejarah Mencari Tbrah: Risalah Sejarah SosialIntelektual Muslim Klasik. Bandung: Citapustaka Media, 2006.

Basit, Abdul. Wacana Dakwah Kontemporer. Yogyakarta: Pustaka Pelajar, 2005.

Deni Darmawan \& Deden Hendra Permana. Desain Dan Pemprograman Website. Bandung, Remaja Rosdakarya, 2013.

Eickelman, Dale F. "New Media in the Arab Middle East and the Emergence of Open Societies', dalam Robert W. Hefner (ed.), Remaking Muslim Politics: Pluralism, Contestation, Democratization. Princeton: Princeton University Press, 2005.

Ghazali (al), Abu Hamid Muhammad. Miyskat al-Anwar wa Mashafat alAsrar. Beirut: Alam al-Kutub, 1986.

Irwansyah. Teknologi Komunikasi Sebagai Eksistensi Kekerabatan: Studi Analisa Jaringan Sosial Kekerabatan Berbasis Teknologi Komunikasi Telepon Seluler. Jakarta: Universitas Indonesia, 2010.

Jhon Naisbitt dan Patricia Aburdene, Megatrends 2000. Jakarta: Binarupa Aksara, 2000.

Larsson, Goran. Muslim and The New Media Historical and contemporary Debates. Farnham: Ashgate, 2001.

Manovich, Lev. "New Media From Borges to HTML." dalam Noah Wardrip- Fruin dan Nick Montfort(eds.), The New Media Reader. Cambridge\& Massachusetts, 2003. 
Masduki. Jurnalistik Radio: Menata Profesianalisme Reported Dan Penyiar. Yogyakarta: LKIS, 2001.

Moore, Wilbert E. Social Verandering" dalam Social Change, terj. A. Basoski \& Prisma Boeken. Utrech” Antwepen, 1965.

Munawar Ahmad Anees dan Alia N. Athar. Guide to Sira and Hadith Literature in Western Language. London: Manshell Publishing Limited, 1986.

Soekanto, Sorjono. Sosiologi Suatu Pengantar. Raja Grafindo Persada, Jakarta, 1994.

Vin Crosbie, Rebuilding Media, http: // rebuildingmedia. corante. Com / archives /2006/04 /27 / what_is_new_media. php. Diakses pada tanggal 30 Mei 2018.

Wibowo, Wahyu (ed). Kedaulatan Frekuensi. Regulasi Penyiaran, Peran KPI dan Konvergensi Media. Jakarta: PT. Kompas Media Nusantara, 2013. 